Research Article

\title{
Dynamics of Archaeal and Bacterial Communities in Response to Variations of Hydraulic Retention Time in an Integrated Anaerobic Fluidized-Bed Membrane Bioreactor Treating Benzothiazole Wastewater
}

\author{
Yue Li, ${ }^{1}$ Qi Hu, ${ }^{1,2}$ and Da-Wen Gao $\mathbb{D D}^{1}$ \\ ${ }^{1}$ State Key Laboratory of Urban Water Resource and Environment, Harbin Institute of Technology, Harbin 150090, China \\ ${ }^{2}$ School of Pharmaceutical Engineering, Shenyang Pharmaceutical University, Shenyang, Liaoning Province 110016, China \\ Correspondence should be addressed to Da-Wen Gao; gaodw_hit@163.com
}

Received 8 February 2018; Accepted 5 April 2018; Published 29 April 2018

Academic Editor: Guangbin Li

Copyright (C) 2018 Yue Li et al. This is an open access article distributed under the Creative Commons Attribution License, which permits unrestricted use, distribution, and reproduction in any medium, provided the original work is properly cited.

\begin{abstract}
An integrated anaerobic fluidized-bed membrane bioreactor (IAFMBR) was investigated to treat synthetic high-strength benzothiazole wastewater $(50 \mathrm{mg} / \mathrm{L})$ at a hydraulic retention time (HRT) of 24,18 , and $12 \mathrm{~h}$. The chemical oxygen demand (COD) removal efficiency (from 93.6\% to 90.9\%), the methane percentage (from 70.9\% to 69.27\%), and the methane yield (from $0.309 \mathrm{~m}^{3} \mathrm{CH}_{4} / \mathrm{kg} \cdot \mathrm{COD}_{\text {removed }}$ to $0.316 \mathrm{~m}^{3} \mathrm{CH}_{4} / \mathrm{kg} \cdot \mathrm{COD}_{\text {removed }}$ ) were not affected by decreasing HRTs. However, it had an adverse effect on membrane fouling (decreasing service period from $5.3 \mathrm{~d}$ to $3.2 \mathrm{~d}$ ) and benzothiazole removal efficiency (reducing it from $97.5 \%$ to $82.3 \%$ ). Three sludge samples that were collected on day 185, day 240, and day 297 were analyzed using an Illumina ${ }^{\circledR}$ MiSeq platform. It is striking that the dominant genus of archaea was always Methanosaeta despite of HRTs. The proportions of Methanosaeta were 80.6\% (HRT 24), 91.9\% (HRT 18), and 91.2\% (HRT 12). The dominant bacterial genera were Clostridium in proportions of 23.9\% (HRT 24), 16.4\% (HRT 18), and 15.3\% (HRT 12), respectively.
\end{abstract}

\section{Introduction}

The widespread use of antibiotics has generated large volumes of contaminated antibiotic wastewater. Antibiotics have not been degraded entirely even after passing through the processing of conventional wastewater treatment plants (WWTP) $[1,2]$. They gradually enter the water environment when wastewater is discharged. Therefore, antibiotics have been detected in surface water $[3,4]$, groundwater, and soils, generating worldwide attention. The occurrence and release of antibiotics have adversely affected bioreactor treatment in decreasing COD removal efficiency because of their bacterial toxicity [5]. Furthermore, antibiotics are considered to be pollutants because antibiotics and their transformation products may lead to spread/transfer of antibiotic-resistant bacteria (ARB) and antibiotic resistance genes (ARGs) when microbes are exposed to antibiotics in the long term.
Among the processes used for wastewater treatment, anaerobic treatment has some technical advantages, such as the production of methane, lower energy costs, and lower excess sludge production [6]. Anaerobic bioreactors have been used for high-strength organic wastewater treatment, including treatment of contaminated antibiotic wastewater $[5,7]$. However, anaerobic bioreactors alone cannot fulfill the demands of stringent effluent standards. To improve effluent quality, some researchers have combined anaerobic and membrane reactors [8-10]. A two-stage anaerobic fluidized-membrane bioreactor reportedly was used to treat municipal wastewater containing 20 pharmaceuticals, achieving pharmaceutical removal efficiencies of $78 \%-100 \%$ [11]. Also, membrane bioreactors could have an advantage in the release of antibiotic-resistant bacteria (genes). Munir et al. have researched the effluent and biosolids of five wastewater utilities in Michigan [12]. They found that membrane 
bioreactor has the least release of antibiotic-resistant bacteria (genes) compared to the four other types of wastewater treatment utilities.

Parameters such as hydraulic retention time (HRT), temperature, and solid retention time (SRT) have a significant effect on the performance and running life of a bioreactor. A large number of different combinations of operation conditions have been reported, such as SRT from a few days [13] to about a year [14], temperature from psychrophilic [15] to thermophilic, and HRT from a few hours [16] to a few days [17]. HRT is one of the essential operating conditions, which has a direct influence on the performance of the bioreactor [17]. In the light of different chemical compositions of antibiotic wastewater, it is important to select the corresponding HRT. The change of performance inevitably affects membrane fouling development in AnMBR. It has been reported that a decrease in HRT enhanced accumulation of soluble microbial products (SMP), which accelerated membrane fouling [18]. Our previous research showed the feasibility of an integrated anaerobic fluidized-bed membrane bioreactor treating synthetic benzothiazole wastewater [10]. However, little information is available about the influence of HRT on IAFMBR treating high-strength benzothiazole wastewater.

This study investigated the feasibility of an integrated anaerobic fluidized-bed membrane bioreactor (IAFMBR) to treat high-strength wastewater containing benzothiazole. This research was focused on the impact of hydraulic retention time (HRT) on the performance of the IAFMBR and the succession of microbial community structures.

\section{Materials and Methods}

2.1. Integrated Anaerobic Fluidized-Bed Membrane Bioreactor. The integrated anaerobic fluidized-bed membrane bioreactor (IAFMBR) was made of $10 \mathrm{~mm}$ Plexiglas with a total volume of $8.9 \mathrm{~L}$ (effective volume of $6.1 \mathrm{~L}$ ) [10]. The reactor consisted of an outer tube, a middle tube, an inner tube, a three-phase separator, and a membrane module (Figure 1). The outer tube was filled with anaerobic granular sludge. A hollow fiber membrane (Mitsubishi Rayon Co., Ltd., Tokyo, Japan) was equipped in the inner zone with a total surface membrane area of $0.21 \mathrm{~m}^{2}$ and a pore diameter of $0.4 \mu \mathrm{m}$. The designed membrane flux was $11.3 \mathrm{~L} / \mathrm{m}^{2} \mathrm{~h}$.

The IAFMBR consisted of an AFBR (anaerobic fluidized-bed reactor) and an AnMBR (anaerobic membrane bioreactor). The AFBR effluent was treated by anaerobic granular sludge. The IAFMBR effluent was a membrane permeate which was treated by anaerobic granular sludge and membrane.

2.2. Reactor Operation Conditions. The reactor had stably operated for $151 \mathrm{~d}$, including a start-up phase (1-58 d) and an adaptation phase (59-151) (Table 1). In this study, the reactor was operated under HRT of $24(152-185 \mathrm{~d}), 18$ (186-240 d), and $12 \mathrm{~h}$ (241-297 d) (Table 1). Continuous membrane filtration was performed. During the whole experiment, the reactor was wrapped with an electrothermal wire to keep the temperature at $35^{\circ} \mathrm{C}$. The SRT was $35 \mathrm{~d}$, and the concentration of benzothiazole was $50 \mathrm{mg} / \mathrm{L}$.
2.3. Inoculation and Feed Composition. The reactor was inoculated with $1.2 \mathrm{~L}$ anaerobic granular sludge that was taken from an anaerobic reactor treating wastewater from an alcohol-producing plant in Daqing, China. The MLVSS was $4850 \mathrm{mg} / \mathrm{L}$, and the MLVSS/MLSS was 0.67 .

Synthetic wastewater was fed according to the characteristics of antibiotic production wastewater coming from a pharmaceutical factory in Harbin, China. The concentration of benzothiazole was $50 \mathrm{mg} / \mathrm{L}$. Glucose and acetate were used to maintain the COD (2961-3337 mg/L). The other compositions of wastewater were as follows (mg/L): $\mathrm{NH}_{4} \mathrm{Cl}, 140$; urea, 40; $\mathrm{KH}_{2} \mathrm{PO} 4,45 ; \mathrm{MgSO}_{4}, 55$; and $\mathrm{CaCl}_{2}, 15$. The inorganic nutrient composed is according to the previous study [8].

2.4. Sample Analysis. The COD was measured according to standard methods [19]. Biogas production was measured using a wet gas meter. Biogas production was detected using a gas chromatograph (Agilent GC 7890A, USA) with a thermal conductivity detector. The sample of VFAs was filtrated with a $0.45 \mu \mathrm{m}$ Millipore filter, and it was determined by a gas chromatograph (Agilent GC 7890, USA) equipped with a flame ionization detector. Benzothiazole concentration was detected by a high-performance liquid chromatography instrument (Waters e2695, USA) under ultraviolet detection set at $254 \mathrm{~nm}$ with a C18 column (SB-C18, $250 \mathrm{~mm} \times 4.6 \mathrm{~mm}$, Agilent Co., Ltd., USA). The mobile phase, flow rate, and temperature were as described previously[10].

The samples of mixed liquor were taken from the reactor. The sample of cake layer was taken from the membrane by flushing the membrane surface with a certain amount of deionized water. The extraction of EPS and SMP was based on [20]. Both SMP and EPS were quantified through a measurement of protein and polysaccharides. The concentration of proteins was detected by the modified BCA kit (Sangon Biotech Ltd., Shanghai, China) following the manufacturer's protocols. The concentration of polysaccharides was determined by the phenol sulphuric acid method [21].

\subsection{Microbial Community Analysis}

2.5.1. Sample Collection and DNA Extraction. The sludge samples (HRT 24, 18, and 12 collected on days 185, 240, and 297, resp.) were taken from the AFBR reactor. Total DNA analysis was performed by extraction using a FastDNA SPIN Kit for Soil (MP Biomedicals (Shanghai) Ltd., China) following the manufacturer's protocols.

2.5.2. PCR Amplification and Illumina ${ }^{\circledR}$ MiSeq Method. PCR amplification, production purification, and quantification were afforded by a sequencing company (Sangon Biotech Ltd., Shanghai, China). The extracted DNA was amplified using a set of bar-coded primers $341 \mathrm{~F}$ and $805 \mathrm{R}$ for bacteria. The amplification of archaea DNA was used using nested PCR (two sets of primers). One set of primers was $340 \mathrm{~F}$ and $1000 \mathrm{R}$, and the other set of primers was $349 \mathrm{~F}$ and $806 \mathrm{R}$. The composition of different primers was reported in the previous study [10].

The thermocycling steps were as follows: $94^{\circ} \mathrm{C}$ for $3 \mathrm{~min}$, followed by 5 cycles at $94^{\circ} \mathrm{C}$ for $30 \mathrm{~s}, 45^{\circ} \mathrm{C}$ for $20 \mathrm{~s}$, and $65^{\circ} \mathrm{C}$ for $30 \mathrm{~s} ; 20$ cycles at $94^{\circ} \mathrm{C}$ for $20 \mathrm{~s}, 55^{\circ} \mathrm{C}$ 


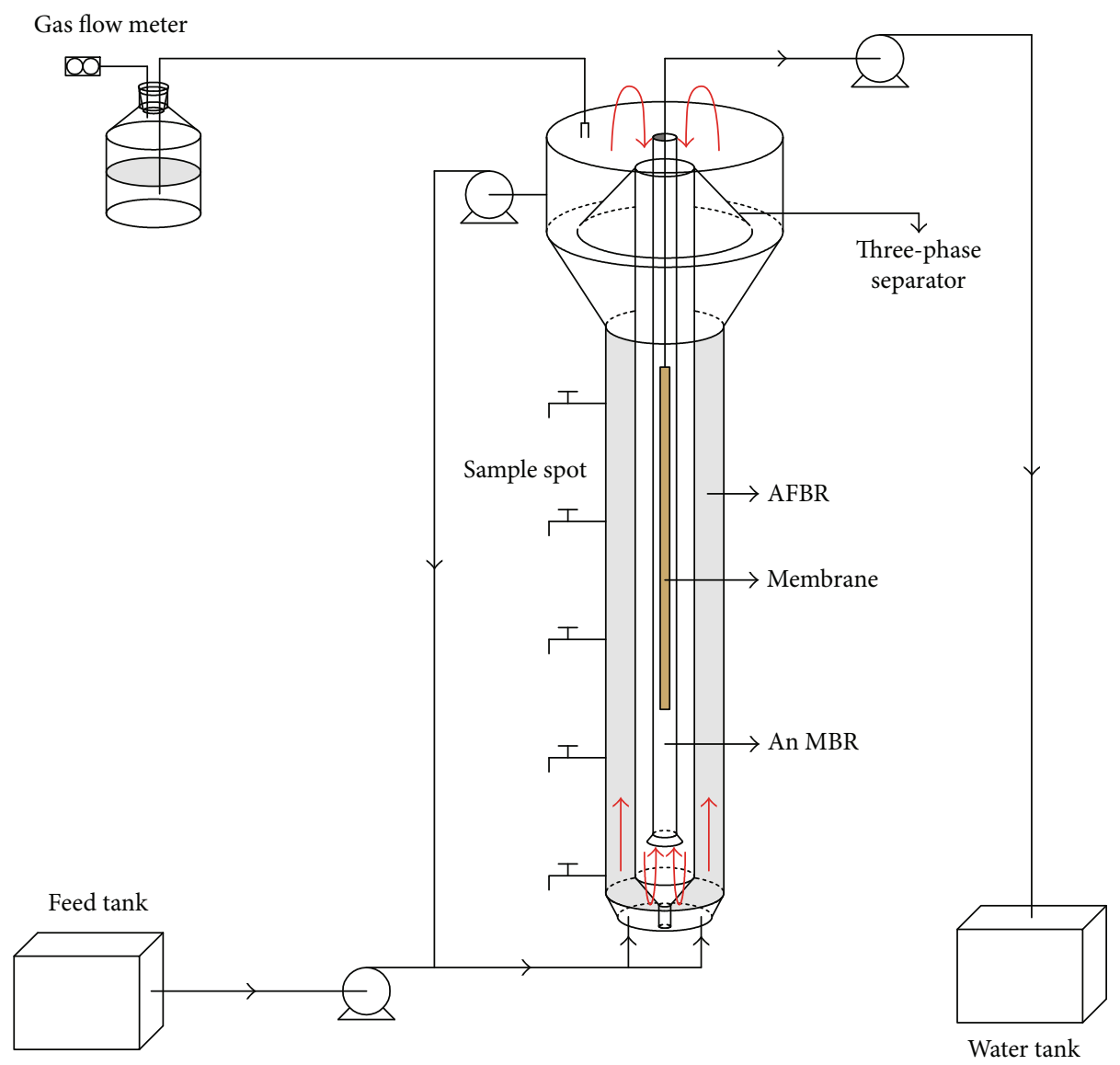

FIGURE 1: The schematic diagram of the IAFMBR.

TABLE 1: The summary of operating conditions of IAFMBR system.

\begin{tabular}{lccccc}
\hline Phase & Start-up & Adaptation & HRT 24 & HRT 18 & HRT 12 \\
\hline Days $(\mathrm{d})$ & $1-58 \mathrm{~d}(58 \mathrm{~d})$ & $59-151 \mathrm{~d}(93 \mathrm{~d})$ & $152-185 \mathrm{~d}(34 \mathrm{~d})$ & $186-240 \mathrm{~d}(55 \mathrm{~d})$ & 50 \\
Benzothiazole $(\mathrm{mg} / \mathrm{L})$ & 0 & $1-50$ & $241-297 \mathrm{~d}(57)$ \\
HRT $(\mathrm{h})$ & 24 & 35 & 24 & 18 & 50 \\
Temperature $\left({ }^{\circ} \mathrm{C}\right)$ & 35 & 3.26 & 35 & 35 & 35 \\
OLR $\left(\mathrm{kg} \mathrm{COD} / \mathrm{m}^{3} \cdot \mathrm{d}\right)$ & 3.33 & & 3.13 & 4.64 & 6.36 \\
\hline
\end{tabular}

for $20 \mathrm{~s}$, and $72^{\circ} \mathrm{C}$ for $30 \mathrm{~s}$; and a final extension step at $72^{\circ} \mathrm{C}$ for $5 \mathrm{~min}$. The PCR productions were sequenced by an Illumina MiSeq high-throughput platform (Sangon Biotech Ltd., Shanghai, China).

2.5.3. Biodiversity Analysis and Phylogenetic Classification. The raw reads were demultiplexed. The adapters, barcode, and primers in all reads were trimmed. Sequences shorter than 200 bp were removed with the PRINSEQ software. The UCHIME software was used to detect chimera sequences [10].

Operational taxonomic units (OTUs) were clustered by 97\% similarity (3\% dissimilarity level) using the UCLUST algorithm (http://www.drive5.com/uclust/downloads1_1579.html). The Shannon index and Chaol index were calculated to compare the diversity and richness of microbial structures [22].

\section{Results and Discussion}

\subsection{Performance of IAFMBR}

3.1.1. COD Removal. The variations of COD were investigated during the three phases (Figure 2). In general, the COD removal efficiency of IAFMBR was relatively stable, and the numerical values were $93.6 \pm 0.6 \%, 91.2 \pm 1.7$, and $90.9 \pm 0.9 \%$ at the HRT of $24 \mathrm{~h}, 18 \mathrm{~h}$, and $12 \mathrm{~h}$. For AFBR, the COD removal efficiency was slightly impacted by the HRT. The COD removal efficiency was maintained at about $87.3 \pm 0.6 \%$ at the HRT of $24 \mathrm{~h}$, and the effluent COD was $398 \mathrm{mg} / \mathrm{L}$. When the HRT was reduced to $18 \mathrm{~h}$, the effluent COD was increased to $828 \mathrm{mg} / \mathrm{L}$ at the beginning and then decreased to $467 \pm 57 \mathrm{mg} / \mathrm{L}$ at a stable period, corresponding to an efficiency of $84.9 \pm 2.1 \%$. However, as the HRT was 


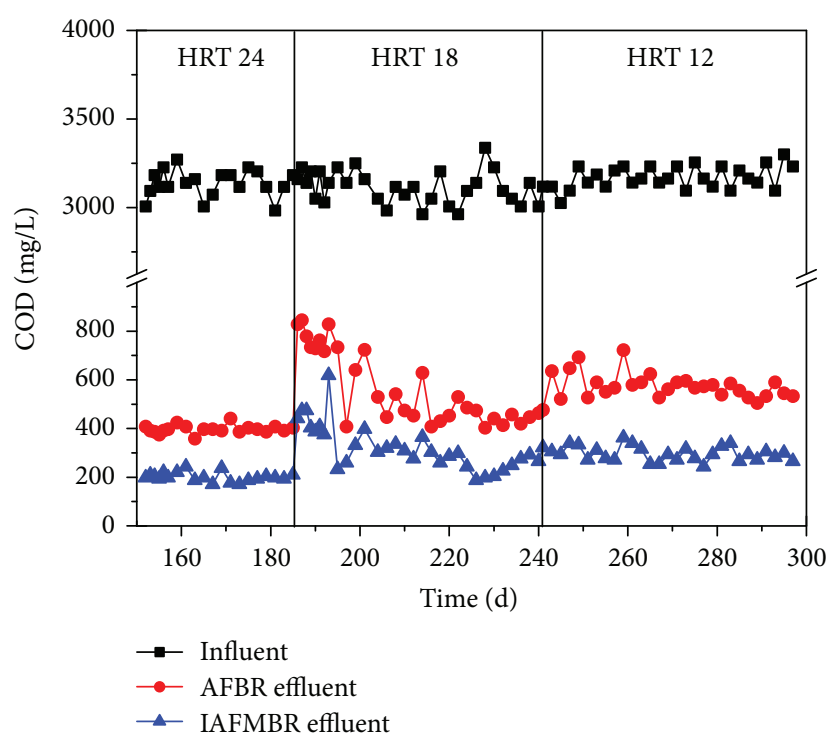

(a)

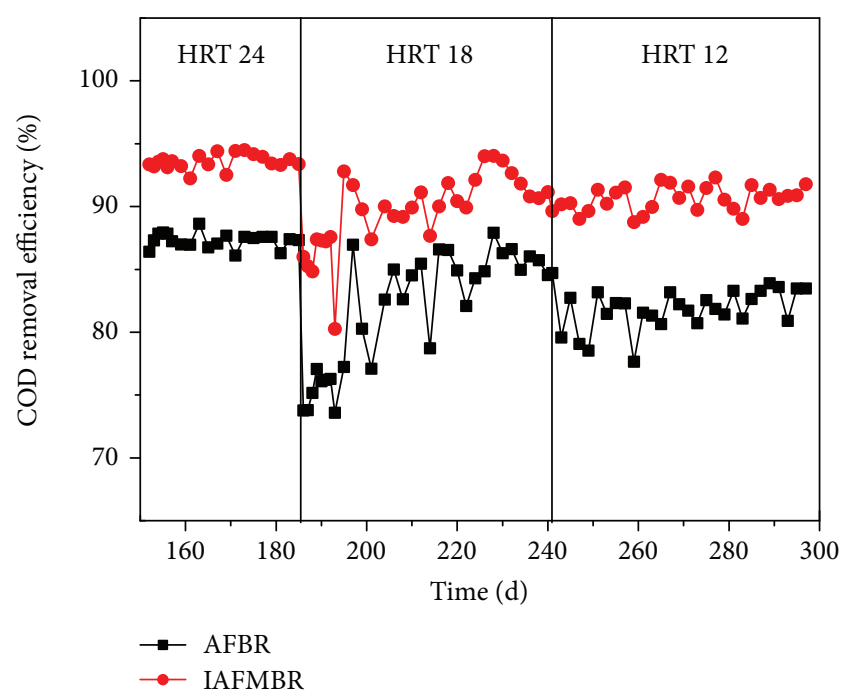

(b)

FIGURE 2: COD removal performance at different HRT. (a) Variations of COD concentration and (b) variations of COD removal efficiency.

reduced to $12 \mathrm{~h}$, the effluent $\mathrm{COD}$ was $557 \pm 28 \mathrm{mg} / \mathrm{L}$, and the COD efficiency was $82.5 \pm 1.1 \%$.

The impact of HRT on the performance has been researched in some studies. The antibiotic wastewater that contained amoxicillin (AMX) was treated by an expanded granular sludge bed (EGSB) at an HRT of 8-20 h, and the COD removal efficiency dropped from $85 \%$ to $36.5 \%$ [23]. Gao et al. used IAFMBR treating domestic wastewater [8]. They found that the COD removal efficiency obviously decreased from $63.6 \pm 2.5 \%$ (HRT 8) to $48.4 \pm 2.6 \%$ (HRT $4)$. Compared to those studies that were previously mentioned, HRT variations did not obviously affect the COD removal efficiency in this study. This is because the synthetic feed (the main carbon sources were glucose and acetate) is easy to biodegrade by microorganisms.

3.1.2. Benzothiazole Removal. Benzothiazole removal efficiency decreased with the stepwise drop of HRT (Figure 3). The average AFBR (IAFMBR) effluent benzothiazole concentrations were $2.03 \pm 0.24 \mathrm{mg} / \mathrm{L} \quad(1.23 \pm 0.27 \mathrm{mg} / \mathrm{L}), \quad 9.60$ $\pm 1.36 \mathrm{mg} / \mathrm{L}(7.28 \pm 1.36 \mathrm{mg} / \mathrm{L})$, and $12.02 \pm 1.71 \mathrm{mg} / \mathrm{L}(8.99$ $\pm 1.89 \mathrm{mg} / \mathrm{L})$ at the HRT of 24,18 , and $12 \mathrm{~h}$. The benzothiazole removal efficiency of AFBR (IAFMBR) was $96.0 \pm 0.5 \%$ $(97.6 \pm 0.5 \%), \quad 81.1 \pm 1.9 \% \quad(85.7 \pm 2.6 \%), \quad$ and $76.4 \pm 3.4 \%$ $(82.3 \pm 3.7 \%)$ at the HRT of 24,18 , and $12 \mathrm{~h}$.

HRT is one of the critical factors that affect the degradation of antibiotics. It has been reported that the main removal pathway of benzothiazole was biodegradation [10]. For biodegradation, the contact time between biodegraded material and sludge was important which affects the treatment efficiency. For AFBR, a lower HRT applied may cause the washout of the functional bacteria that is required for the biodegradation of antibiotics [24]. For IAFMBR, the functional microbe could wash out and into the inner tube. However, the membrane fouling cycle was relatively short resulting in frequent membrane cleaning. The functional microbe could not enrich in the inner tube.

3.1.3. VFA Accumulation. The accumulation and composition of the volatile fatty acids (VFAs) were supervised in different HRT (Figure 4). Acetate was the major component of VFAs in the AFBR effluent, which increased with the change of HRT, and its concentrations in the AFBR effluent were $88.44 \pm 11.84 \mathrm{mg} / \mathrm{L}(\mathrm{HRT} 24 \mathrm{~h}), 206.93 \pm 15.58 \mathrm{mg} / \mathrm{L}$ (HRT $18 \mathrm{~h}$ ), and $242.82 \pm 9.55 \mathrm{mg} / \mathrm{L}$ (HRT $12 \mathrm{~h}$ ), being accounted as about $73.31 \%, 69.98 \%$, and $68.26 \%$ of total VFAS, respectively. The same phenomenon of acetate accumulation was also indicated in previous studies $[8,10]$. Acetate is the substrate for acetotrophic methanogens which play an important role in $\mathrm{CH}_{4}$ production and for homoacetogenic bacteria, transforming acetate to hydrogen and $\mathrm{CO}_{2}$ [25].

The increment of propionate increased slightly, and its concentrations were $15.86 \pm 3.31 \mathrm{mg} / \mathrm{L}, 18.84 \pm 5.75 \mathrm{mg} / \mathrm{L}$, and $23.01 \pm 0.79 \mathrm{mg} / \mathrm{L}$ at the HRT of 24,18 , and $12 \mathrm{~h}$ in the AFBR effluent. The concentration of butyrate increased from $16.33 \pm 3.07 \mathrm{mg} / \mathrm{L}$ (HRT $24 \mathrm{~h}$ ) to $69.93 \pm 9.10 \mathrm{mg} / \mathrm{L}$ (HRT $18 \mathrm{~h}$ ) to $89.91 \pm 4.14 \mathrm{mg} / \mathrm{L}$ (HRT $12 \mathrm{~h}$ ) in the AFBR effluent, being accounted as about $13.54 \%, 23.65 \%$, and $25.27 \%$ of total VFAs, respectively. It was reported that antibiotics had an adverse effect on butyrate-oxidizing bacteria [25]. In this study, the residual concentration of benzothiazole increased with a decreased HRT (Figure 3), which could inhibit butyrate degradation. A similar inhibition of butyrate degradation was found in other antibiotics [26]. Valerate was not detected during all periods.

In general, tVFA accumulation increased with the declining HRT. The tVFAs in IAFMBR effluent was lower than those in AFBR, which were $57.83 \mathrm{mg} / \mathrm{L} \pm 13.81 \mathrm{mg} / \mathrm{L}$, $154.66 \pm 18.50 \mathrm{mg} / \mathrm{L}$, and $171.04 \pm 10.88 \mathrm{mg} / \mathrm{L}$ at the HRT of $24 \mathrm{~h}, 18 \mathrm{~h}$, and $12 \mathrm{~h}$. 


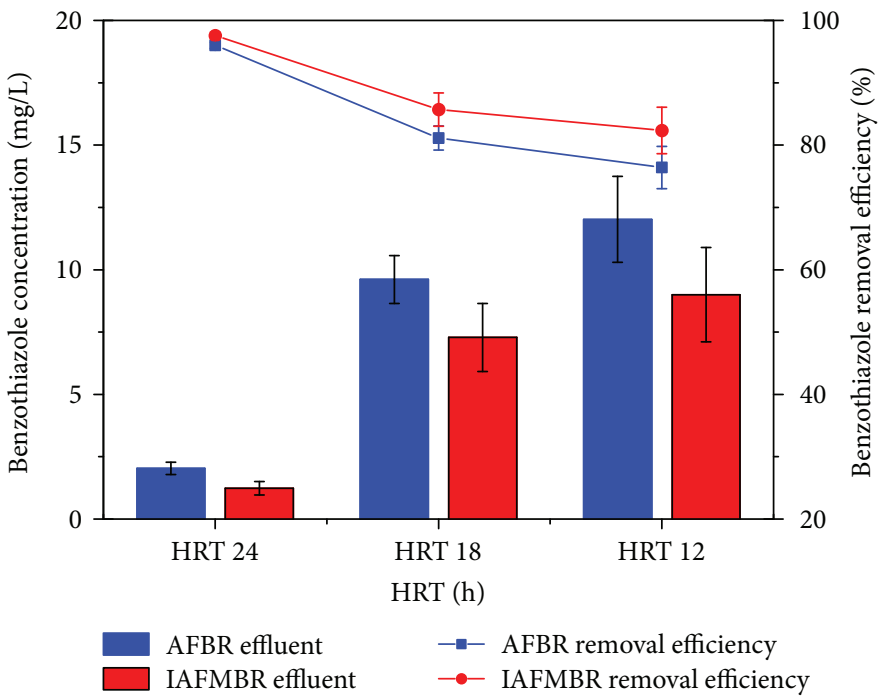

FIgURE 3: The variations of benzothiazole removal performance at different HRT.

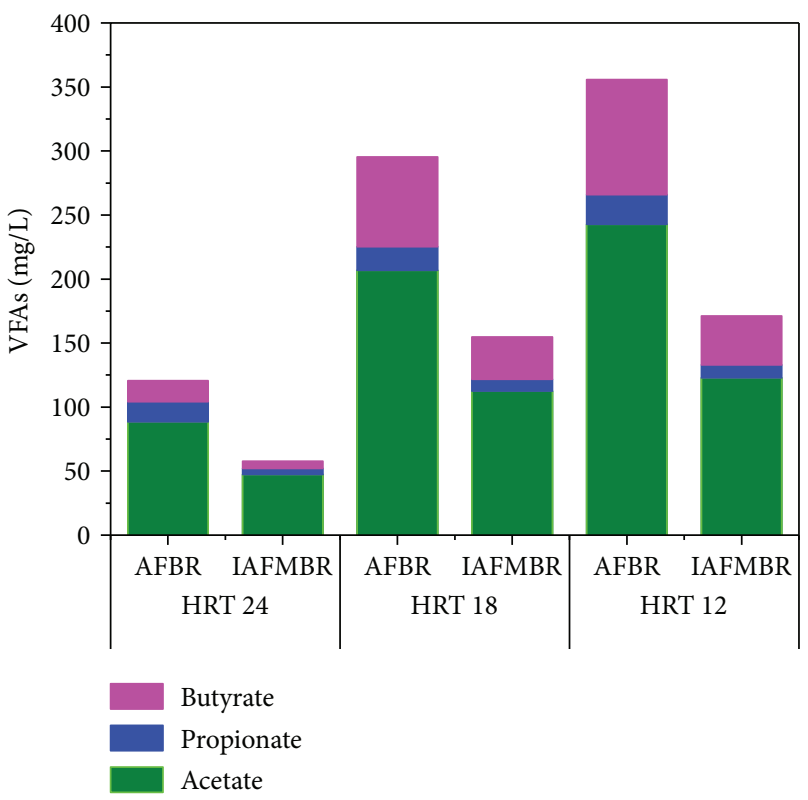

FIgURE 4: VFA accumulation during different HRT (average value) in AFBR and IAFMBR.

3.1.4. Biogas Production. Biogas production was monitored throughout the three phases of reactor operation (Table 2), particularly for the evaluation of methanogenic activity. The biogas production volume was greatest at HRT of $12 \mathrm{~h}$ $(21.49 \pm 0.39 \mathrm{~L} / \mathrm{d})$ compared with that of HRT of $18(14.00$ $\pm 0.78 \mathrm{~L} / \mathrm{d})$ and $24 \mathrm{~h}(10.74 \pm 0.39 \mathrm{~L} / \mathrm{d})$. Methane production apparently increased from $7.60 \pm 0.26 \mathrm{~L} / \mathrm{d}$ to $10.29 \pm 0.57 \mathrm{~L} / \mathrm{d}$ to $14.88 \pm 1.57 \mathrm{~L} / \mathrm{d}$ at HRT of 24,18 , and $12 \mathrm{~h}$. These data showed that methane production augmented with an increase in the organic loading rate, which was similar to previous studies [8].

However, the methane percentage was slightly affected by the change of HRT $(70.9 \pm 0.3 \%, 73.5 \pm 2.1 \%$, and $69.3 \pm 1.6 \%$ at HRT of 24,18 , and $12 \mathrm{~h}$ ). About $70 \%$ methane content was
TABLE 2: The biogas production at different HRTs (average concentrations at steady-states).

\begin{tabular}{ccccc}
\hline HRT & $\begin{array}{c}\text { Biogas } \\
\text { production } \\
(\mathrm{L} / \mathrm{d})\end{array}$ & $\begin{array}{c}\text { Methane } \\
\text { production } \\
(\mathrm{L} / \mathrm{d})\end{array}$ & $\begin{array}{c}\text { Methane } \\
\text { percentage } \\
(\%)\end{array}$ & $\begin{array}{c}\text { Methane yield }\left(\mathrm{m}^{3}\right. \\
\mathrm{CH}_{4} / \\
\left.\mathrm{kg} \cdot \mathrm{COD}_{\text {removed }}\right)\end{array}$ \\
\hline 24 & $10.74 \pm 0.39$ & $7.60 \pm 0.26$ & $70.9 \pm 0.3$ & $0.309 \pm 0.014$ \\
18 & $14.00 \pm 0.78$ & $10.29 \pm 0.57$ & $73.5 \pm 2.1$ & $0.327 \pm 0.028$ \\
12 & $21.49 \pm 1.26$ & $14.88 \pm 1.57$ & $69.3 \pm 1.6$ & $0.316 \pm 0.022$ \\
\hline
\end{tabular}

similar to previous studies [25]. The methane yield is a useful parameter to evaluate the performance of an anaerobic reactor [5]. The methane yield was relatively stable, and the values were $0.309 \pm 0.014 \mathrm{~m}^{3} \mathrm{CH}_{4} / \mathrm{kg} \mathrm{COD}$ removed (HRT24), $0.327 \pm 0.028 \mathrm{~m}^{3} \mathrm{CH}_{4} / \mathrm{kg} \mathrm{COD}$ removed (HRT18), and 0.316 $\pm 0.022 \mathrm{~m}^{3} \mathrm{CH}_{4} / \mathrm{kg} \mathrm{COD}$ removed (HRT12), respectively. There are two possible reasons. On the one hand, methanogens were in the anaerobic granular sludge. This structure protected the activity of methanogens. On the other hand, the effect of BTH on the methanogens was not significant.

In order to show the carbon flow, a mass balance (based on COD) was illustrated (Figure 5(a)). About 70\% carbons were converted to methane at different HRT. The data of mass balance and methane yield (Table 2) was similar, which showed that the production of methane was not affected by the reducing HRT.

\subsection{Membrane Fouling}

3.2.1. TMP Fraction. The change of transmembrane pressure (TMP) was used as an indicator of membrane fouling. Cleanup or backflushing was not applied in order to detect the onetime operational duration of membrane fouling. In this experiment, the TMP was collected at the stable period of different HRTs, and the value of TMP reached $16 \mathrm{kPa}$ as membrane fouling.

In general, the trends of the membrane fouling cycle were similar at different HRT (Figure 5(b)). The membrane fouling cycle was 5.3, 3.7, and 3.2 d at HRT of 24,18 , and $12 \mathrm{~h}$. 

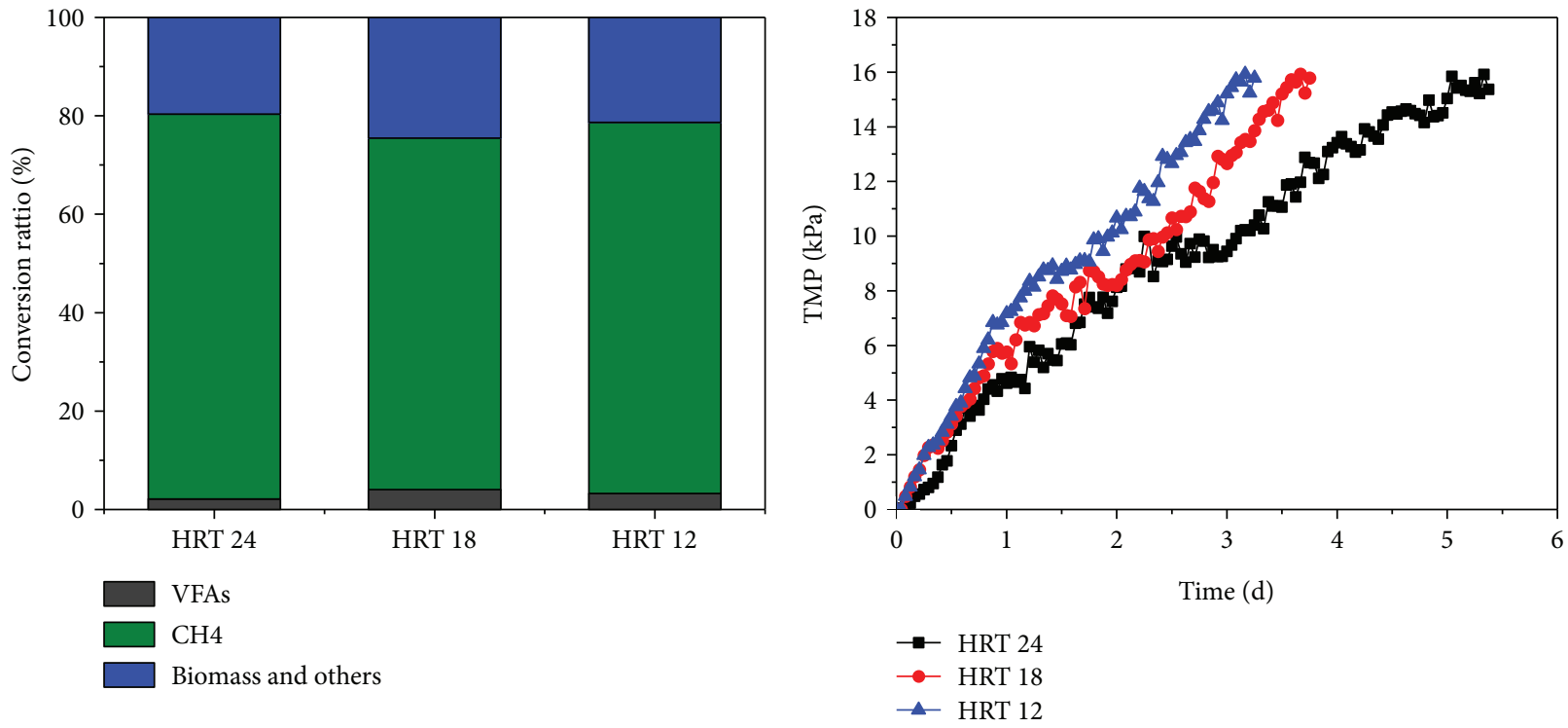

(a)

(b)

FIgURE 5: Mass balance and transmembrane pressure (TMP). (a) Mass balance at different HRT and (b) TMP profile at different HRT.

When HRT was $24 \mathrm{~h}$, the TMP rapidly increased to $9 \mathrm{kPa}$ on day 2.4 in a linear manner and then had transient platform fluctuations. Finally, TMP was close to $16 \mathrm{kPa}$ on day $5.3 \mathrm{in}$ a linear manner again.

Generally, with the shortened HRT, the influent COD of AnMBR was increased (from $398 \mathrm{mg} / \mathrm{L}$ to $557 \mathrm{mg} / \mathrm{L}$ ) (Figure 2(a)), which led to the decrease in the membrane fouling cycle. These results were similar to previous studies [8]. Gao et al. have researched the control of membrane fouling by addition of granular-activated carbon (GAC) at HRT 4,6 , and $8 \mathrm{~h}$ in an anaerobic membrane bioreactor. They found that the membrane fouling cycle at HRT $4 \mathrm{~h}$ (about $15 \mathrm{~d}$ ) was almost two times of that at HRT $8 \mathrm{~h}$ (about $31 \mathrm{~d}$ ) when $40 \mathrm{~g}$ GAC was added. The membrane fouling cycle of this study was obviously short. The possible reasons are as follows: (1) no addition of GAC. The fluidization of GAC could evidently reduce TMP [16]. However, maintenance of the fluidization of GAC demands a lot of energy to consume. (2) The feed had high COD (2961-3337 mg/L) and antibiotic $(50 \mathrm{mg} / \mathrm{L}$ benzothiazole), which resulted in aggravation membrane fouling.

3.2.2. EPS and SMP Fraction. The variations of EPS and SMP, from both mixed liquor and cake layer, in different TMPs were detected (Figure 6). In the mixed liquor, there was no significant difference in SMP under different HRT. For instance, when the HRT was $24 \mathrm{~h}$, the SMP were $43.00 \mathrm{mg} /$ $\mathrm{L}, 48.19 \mathrm{mg} / \mathrm{L}$, and $47.88 \mathrm{mg} / \mathrm{L}$ at TMP of $5 \mathrm{kPa}, 10 \mathrm{kPa}$, and $15 \mathrm{kPa}$, respectively (Figure 6(a)). The concentrations of EPS and SMP were different at HRT 24, 18, and $12 \mathrm{~h}$ in the mixed liquor, but the trends were similar. EPS and SMP were not affected by TMP variations in each certain HRT with stable performance (Figures 6(a) and 6(c)). The possible reason was that the mixed liquor and microbiology communities were relatively stable, which did not change with TMP.
However, for cake layer, the concentrations of EPS and SMP increased with rising TMP in each certain HRT (Figures 6(b) and 6(d)). For instance, when the HRT was $24 \mathrm{~h}$, the SMP were $22.28 \mathrm{mg} / \mathrm{L}, 34.74 \mathrm{mg} / \mathrm{L}$, and $50.73 \mathrm{mg} / \mathrm{L}$ at TMP of $5 \mathrm{kPa}, 10 \mathrm{kPa}$, and $15 \mathrm{kPa}$, respectively. Those EPS and SMP in the cake layer came from the biomass growth with rising TMP on the membrane surface. Sludge cake formation on the membrane surface is viewed as the major cause of membrane fouling [27]. It has been reported that cake sludge deposited on the membrane surface has much higher specific filtration resistance than that of bulk sludge liquor [28].

The concentrations of EPS and SMP in mixed liquor and the cake layer increased with decreasing HRT, which was due first to the faster growth of anaerobic sludge with shorter HRT [18]; secondly, more undegraded substrates were present in the mixed liquor. It has been reported that SMP occurs in response to environmental stress, such as that caused by toxic compounds [29]. In this study, the concentration of benzothiazole was increased (from $1.23 \pm 0.27 \mathrm{mg} / \mathrm{L}$ to $12.02 \pm 1.71 \mathrm{mg} / \mathrm{L}$ ) with the change of HRT, which could explain the increasing SMP. The major fraction of SMP was the soluble phase of EPS, and SMP consistently varied with EPS in the aerobic MBR [30].

The concentration of protein was much higher than that of polysaccharide either in mixed liquor or cake layer, in EPS or SMP, which was consistent with previous studies[8]. Meng et al. found that proteins are more hydrophobic, adhere more easily to the membrane surface, and induce membrane fouling [31]. In addition, our group has reported that protein had a negative impact on membrane fouling compared to polysaccharide [32]. This conclusion explained the cause of serious membrane fouling in another aspect.

3.3. Microbial Community Structure. Normally, bacteria play a dominant role in antibiotic wastewater treatment systems: 


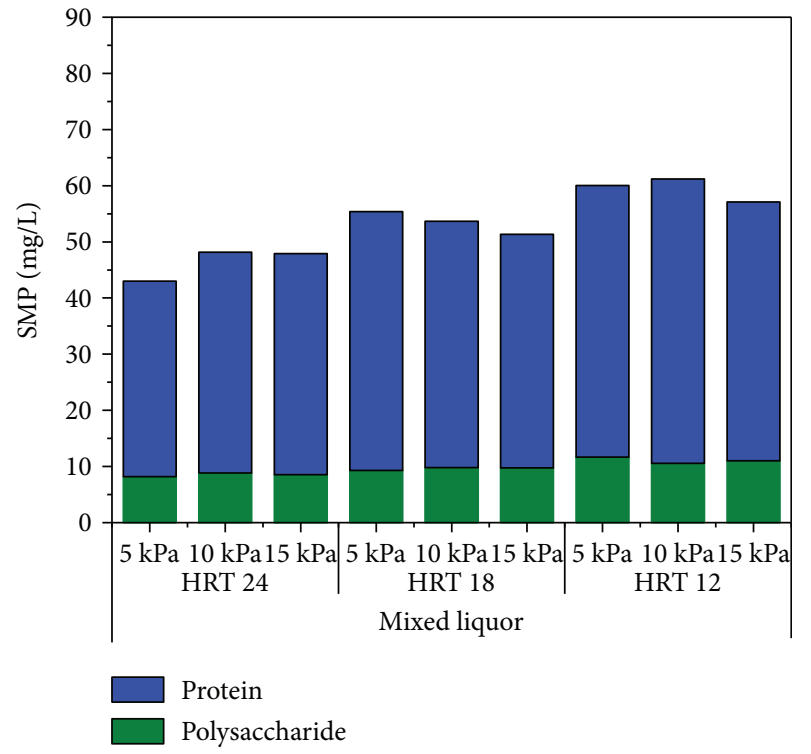

(a)

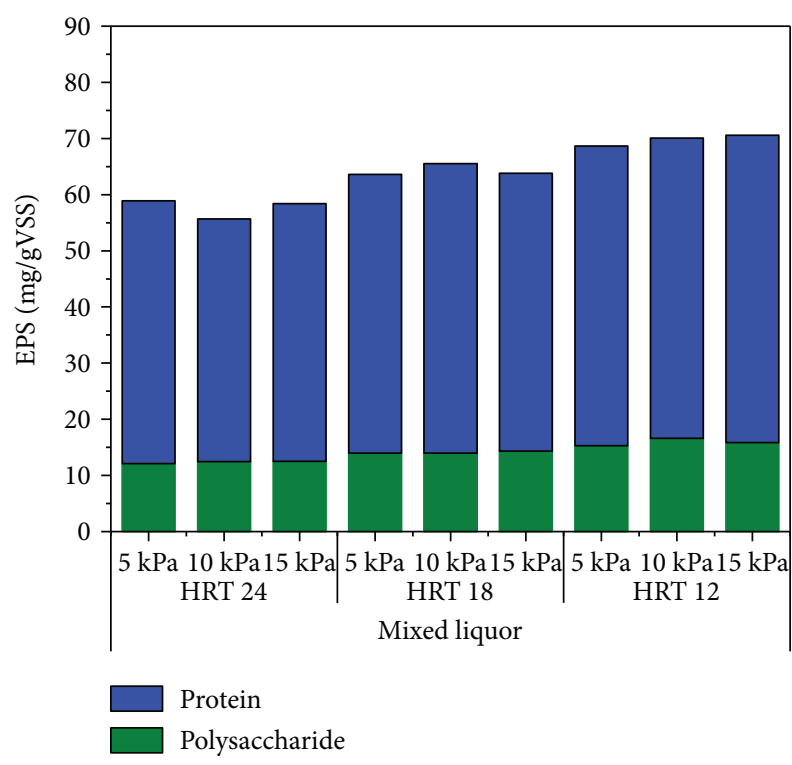

(c)

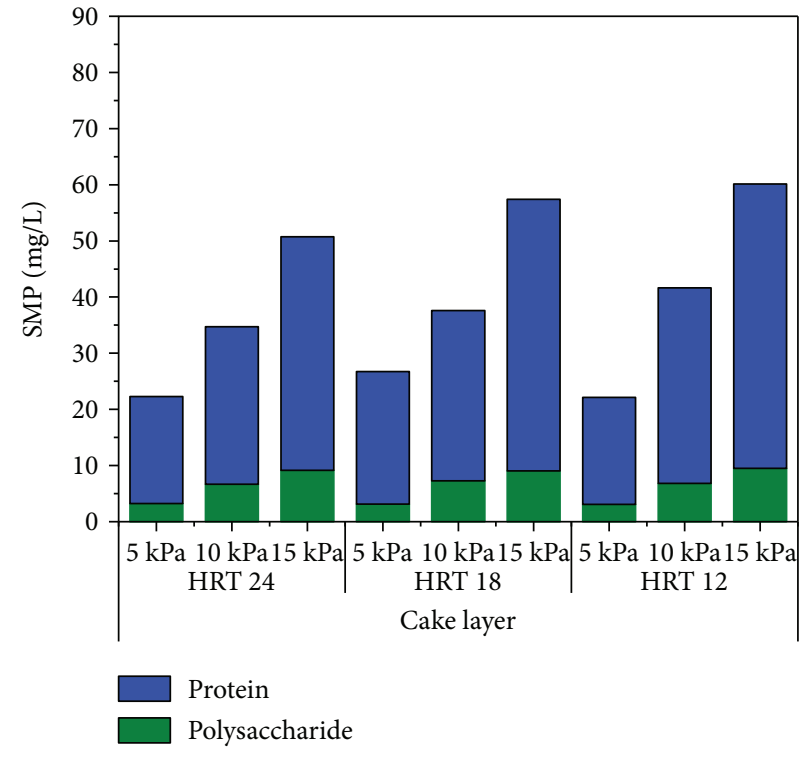

(b)

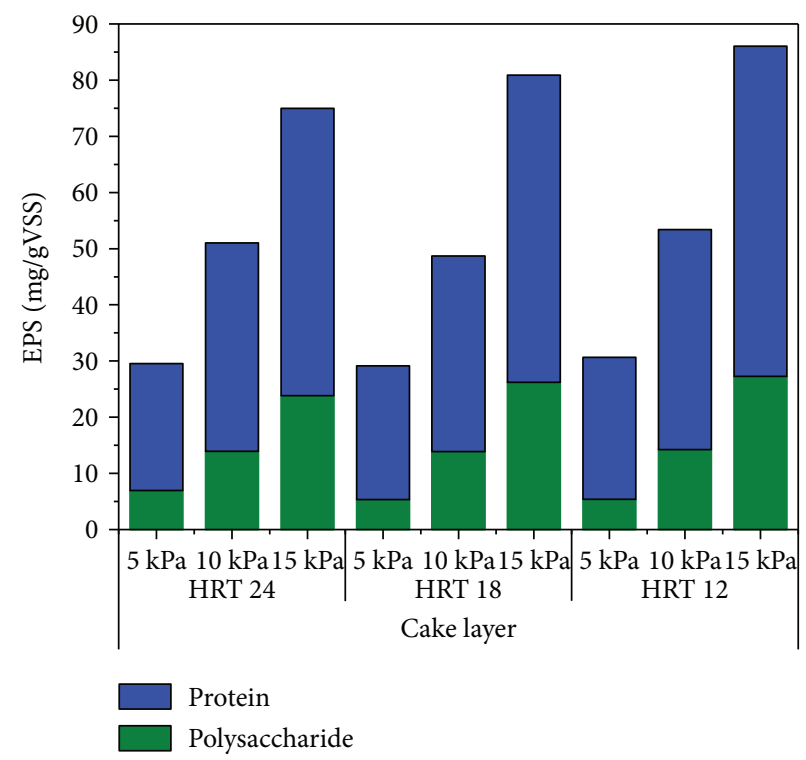

(d)

FIGURE 6: The variation of extracellular polymeric substances (EPS) and soluble microbial products (SMP) in the mixed liquor and cake layer. (a) The SMP in the mixed liquor, (b) the SMP in the cake layer, (c) the EPS in the mixed liquor, and (d) the EPS in the cake layer.

bacteria carbon transformation functions may be disturbed. Meanwhile, bacteria possessing antibiotic resistance could survive in this condition [33]. That is why it is important to understand the microbial community structure.

3.3.1. Bacterial Community Analysis. The Illumina MiSeq high-throughput platform was used to determine three microbial samples (HRT 24, 18, and 12 collected on days 185,240 , and 297, resp.), which were taken from the AFBR. The qualified sequencing reads were in the range of 24,182 to 42,241 , which were clustered in more than 1500 OTUs based on a threshold of $97 \%$.

The relative abundance of phylum, class, and genus levels was described in order to understand the communities better.
More than 20 types of bacterial phyla were recovered altogether, and the main phyla were Firmicutes $(27.7 \%-41.4 \%)$, Proteobacteria (8.9\%-21.6\%), Chloroflexi (12.4\%-25.3\%), and Bacteroidetes (8.3\%-9.4\%) (Figure 7(a)). These phyla were found to be significant microbial groups in other anaerobic bioreactors treating antibiotic wastewater $[7,9,10]$.

At the class level, two of the most important classes were Clostridia (21.2\%-30.2\%) and Anaerolineae (10.9\%-23.2\%), (Figure 7(b)). The sample of HRT 24 was dominated by Clostridia $(30.2 \%)$, Anaerolineae (10.9\%), and $\delta$-Proteobacteria (9.6\%). The HRT 18 community was dominated by Clostridia $(30.2 \%)$, followed by $\gamma$-Proteobacteria $(18.4 \%)$ and Anaerolineae (17.6\%). The HRT 12 community was dominated by Anaerolineae (23.2\%) and Clostridia (21.2\%). 


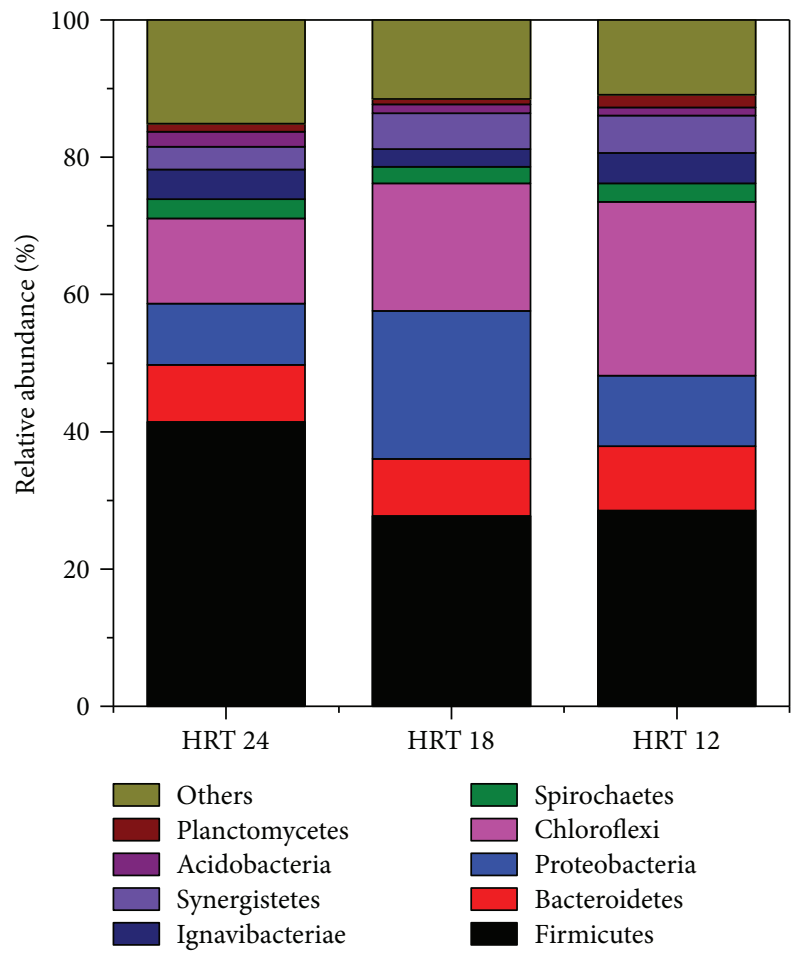

(a)

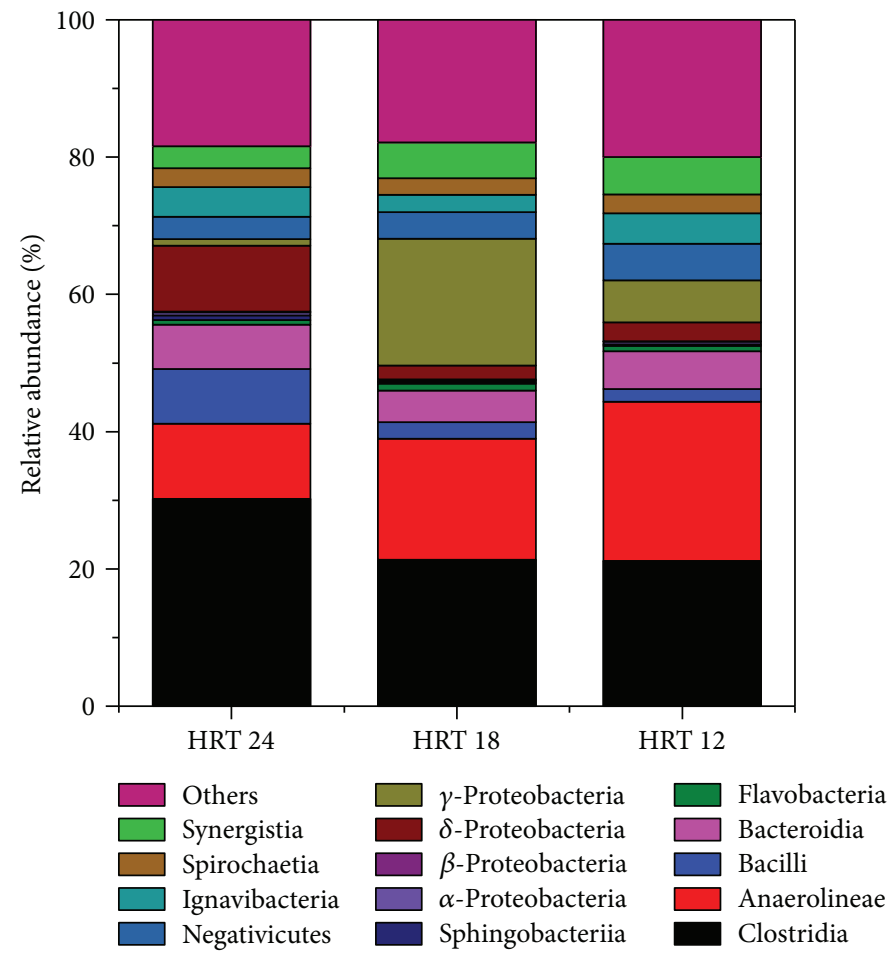

(b)
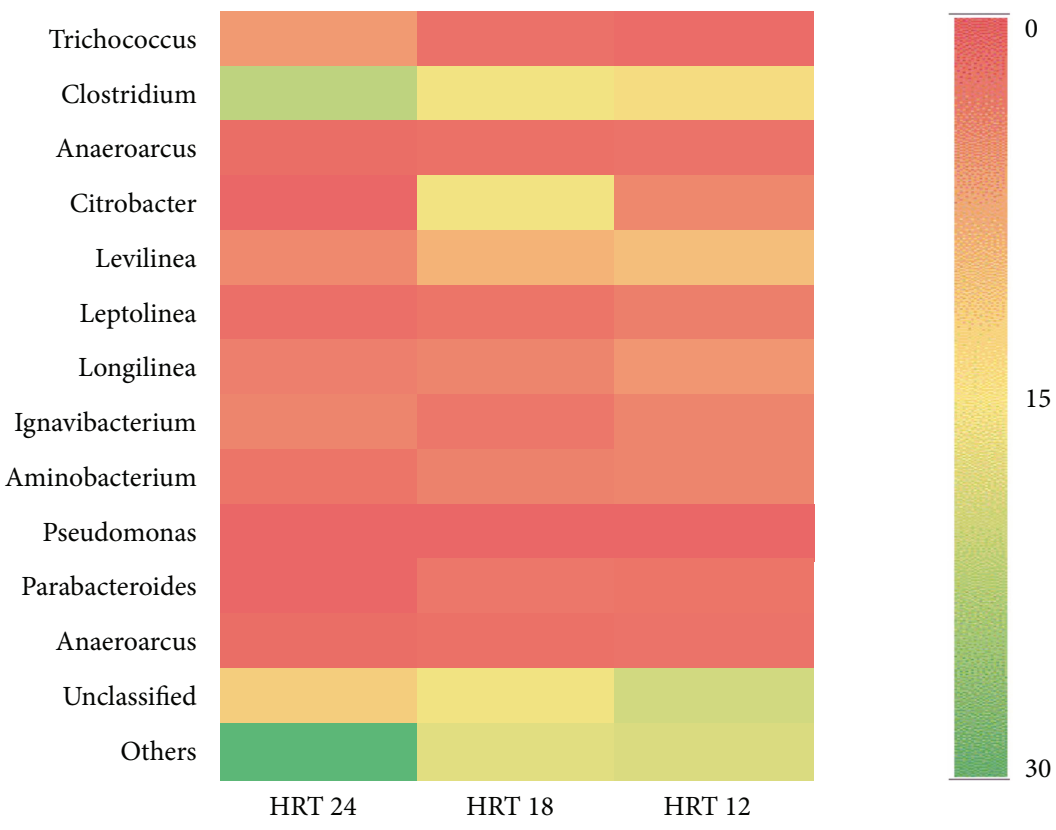

(c)

Figure 7: Continued. 


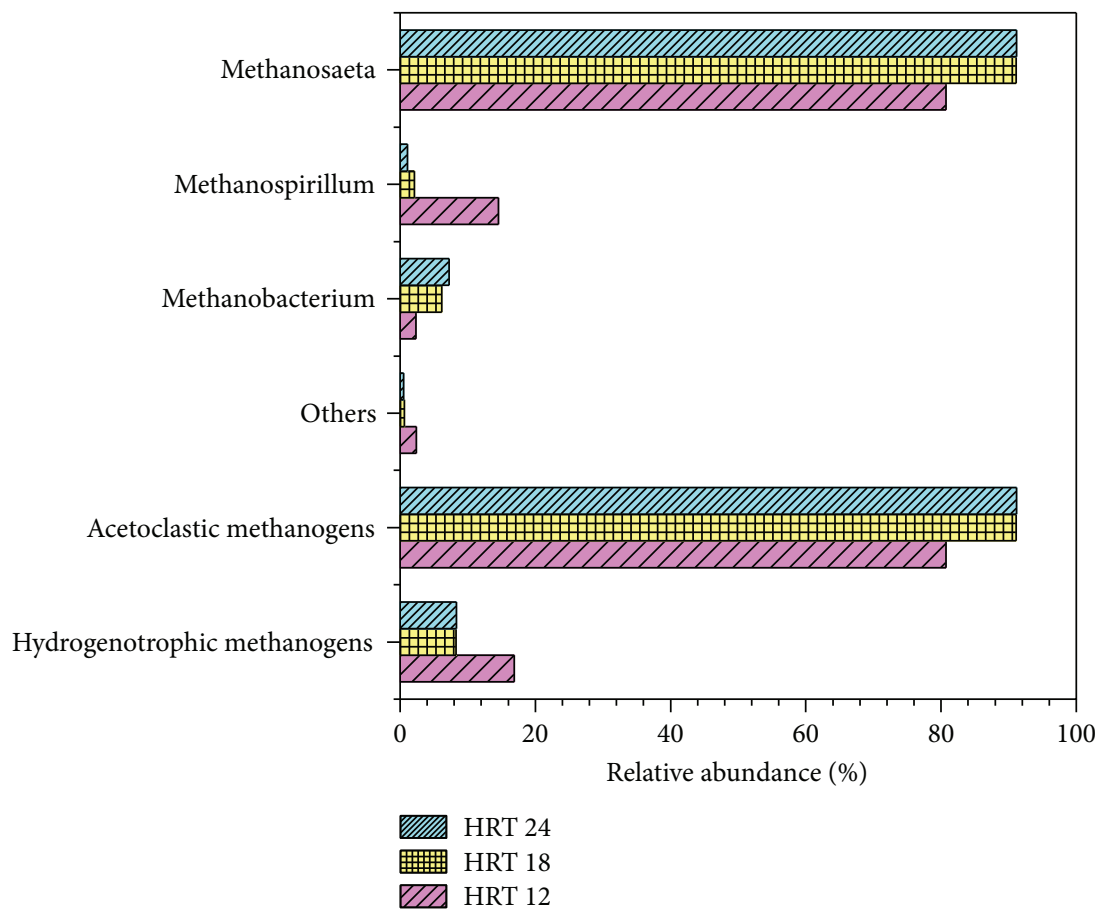

(d)

FIGURE 7: Taxonomic classification of bacteria and archaea form different HRT (collected on day 185, 240, and 297): (a) bacteria phylum, (b) bacteria class, (c) bacteria genus, and (d) archaea genus.

Clostridia had many carbon-degrading functions, which played a main role in COD removal. Some Clostridia were able to cleave aromatic rings and utilize the methyl group of aromatic methyl ethers as carbon source [34, 35]. Clostridia and $\delta$-Proteobacteria were the major classes associated with antibiotic environments [33,36]. Moreover, Anaerolineae was found in an anaerobic bioreactor [37].

In general, microbes from two samples showed similar diversities but different abundance. The sample of HRT 24 was dominant by Clostridium (23.9\%), followed by Trichococcus (6.9\%), and Levilinea (4.8\%). The major community in a sample of HRT 18 was Clostridium (16.4\%), followed by Citrobacter (16.3\%) and Levilinea (10.0\%). The sample of HRT 18 was dominant by Clostridium, Levilinea, and Longilinea in the proportion of $15.3 \%, 11.6 \%$, and 6.3\% (Figure 7(c)).

In this study, no matter how the condition changes, Clostridium was the dominant genus, which was a common genus of dominant bacteria in anaerobic bioreactors [38, 39]. Clostridium belonging to phyla of Firmicutes with hard cell walls can produce endospores. Clostridium spp. were reported to have the ability of degrading complex organic matters from acid by producing or secreting hydrolases, such as protease and $\alpha$-amylase[40]. The relative abundance of some genera was increased in response to HRT, such as Levilinea, Leptolinea, and Longilinea. Levilinea, Leptolinea, and Longilinea are Gram-negative, belonging to the class of Anaerolineae and phyla of Chloroflexi with flexible filaments $[41,42]$. Meanwhile, the decreasing HRT led to the increasing residual concentration of benzothiazole. This phenomenon indicated that the three genera could be inclined to develop in residual benzothiazole.
3.3.2. Archaeal Community Analysis. Over 30,000 qualified sequences were produced by an Illumina MiSeq highthroughput platform. The dominant genus of the archaeal community was Methanosaeta in proportions of $80.8 \%$ (HRT 24), 91.1\% (HRT 18), and 91.2\% (HRT 12) followed by Methanospirillum $(14.5 \%, 2.1 \%$, and $1.1 \%$ in HRT 24,18 , and 12 , resp.) and Methanobacterium (2.3\%, 6.1\%, and 7.3\% in HRT 24, 18, and 12, resp.) (Figure 7(d)). The proportion of acetotrophic methanogens (Methanosaeta) increased from $80.8 \%$ to $91.2 \%$, and the proportion of hydrogenotrophic methanogens (Methanospirillum and Methanobacterium) decreased from $16.9 \%$ to $8.3 \%$. Overall, the dominant participant was always Methanosaeta (acetotrophic methanogens), no matter how the HRT changes.

Methanosaeta was an important archaea in anaerobic bioreactors [43, 44]. Methanosaeta belongs to acetotrophic methanogens which can convert acetic acid to methane and $\mathrm{CO}_{2}$, and this process produces $70 \%$ of methane [45]. Wang et al. treated brewery wastewater using a continuous stirred microbial electrochemical reactor (CSMER) [37]. The CSMER comprised a complete mixing zone (CMZ) and microbial electrochemical zone (MEZ), and the anaerobic sludge was inoculated in CMZ. They found that Methanosaeta (40.3\%) was the predominant archaea in $\mathrm{CSMER}_{\mathrm{CMZ}}$ and Methanosaeta existed in each sample. Methanosaeta have been found to have high methane yield so that the higher relative abundance of Methanosaeta manifested a favorable condition for methane yield [46]. And this finding was in line with the higher methane yield in HRT $18\left(0.327 \mathrm{~m}^{3} \mathrm{CH}_{4} / \mathrm{kg}\right.$ $\left.\mathrm{COD}_{\text {removal }}\right)$ and $12\left(0.327 \mathrm{~m}^{3} \mathrm{CH}_{4} / \mathrm{kg} \mathrm{COD}\right.$ removal $)$ compared with HRT $24\left(0.315 \mathrm{~m}^{3} \mathrm{CH}_{4} / \mathrm{kg} \mathrm{COD}_{\text {removal }}\right)$. 


\section{Conclusions}

This study indicated the feasibility of an IAFMBR to the treatment of high concentration wastewater containing antibiotics at different HRT. The COD removal efficiency, the methane percentage, and the methane yield were not affected by HRT decreasing from $24 \mathrm{~h}$ to $12 \mathrm{~h}$. The decreased HRT had an adverse effect on membrane fouling and benzothiazole removal efficiency. For bacteria, the dominant phyla, class, and genera were Firmicutes, Clostridia, and Clostridium. For archaea, the dominant genera were Methanosaeta. With the decreased HRT, the acetotrophic methanogens increased while that of hydrogenotrophic methanogens decreased. The best performance was obtained at HRT of $24 \mathrm{~h}$.

\section{Conflicts of Interest}

The authors declare that they have no conflicts of interest.

\section{Acknowledgments}

This work was supported by the Natural Science Foundation of Heilongjiang Province (no. ZD201412) and Major Science and Technology Program for Water Pollution Control and Management (2013ZX07201007-001).

\section{References}

[1] S. Castiglioni, R. Bagnati, R. Fanelli, F. Pomati, D. Calamari, and E. Zuccato, "Removal of pharmaceuticals in sewage treatment plants in Italy," Environmental Science \& Technology, vol. 40, no. 1, pp. 357-363, 2006.

[2] A. Y.-C. Lin, T.-H. Yu, and S. K. Lateef, "Removal of pharmaceuticals in secondary wastewater treatment processes in Taiwan," Journal of Hazardous Materials, vol. 167, no. 1-3, pp. 1163-1169, 2009.

[3] B. Halling-Sørensen, S. Nors Nielsen, P. F. Lanzky, F. Ingerslev, H. C. Holten Lützhøft, and S. E. Jørgensen, "Occurrence, fate and effects of pharmaceutical substances in the environment-a review," Chemosphere, vol. 36, no. 2, pp. 357-393, 1998.

[4] K. Kümmerer, Pharmaceuticals in the Environment: Sources, Fate, Effects and Risks, Springer Science and Business Media, Berlin/Heidelberg, Germany, 2008.

[5] S. Chelliapan, T. Wilby, and P. J. Sallis, "Performance of an upflow anaerobic stage reactor (UASR) in the treatment of pharmaceutical wastewater containing macrolide antibiotics," Water Research, vol. 40, no. 3, pp. 507-516, 2006.

[6] B. Lew, S. Tarre, M. Beliavski, C. Dosoretz, and M. Green, "Anaerobic membrane bioreactor (AnMBR) for domestic wastewater treatment," Desalination, vol. 243, no. 1-3, pp. 251-257, 2009.

[7] L. W. Meng, X. K. Li, K. Wang, K. L. Ma, and J. Zhang, "Influence of the amoxicillin concentration on organics removal and microbial community structure in an anaerobic EGSB reactor treating with antibiotic wastewater," Chemical Engineering Journal, vol. 274, no. 15, pp. 94-101, 2015.

[8] D.-W. Gao, Q. Hu, C. Yao, N.-Q. Ren, and W.-M. Wu, "Integrated anaerobic fluidized-bed membrane bioreactor for domestic wastewater treatment," Chemical Engineering Journal, vol. 240, pp. 362-368, 2014.
[9] G. Qiu, Y.-h. Song, P. Zeng, L. Duan, and S. Xiao, "Characterization of bacterial communities in hybrid upflow anaerobic sludge blanket (UASB)-membrane bioreactor (MBR) process for berberine antibiotic wastewater treatment," Bioresource Technology, vol. 142, pp. 52-62, 2013.

[10] Y. Li, Q. Hu, C.-H. Chen, X.-L. Wang, and D.-W. Gao, "Performance and microbial community structure in an integrated anaerobic fluidized-bed membrane bioreactor treating synthetic benzothiazole contaminated wastewater," Bioresource Technology, vol. 236, pp. 1-10, 2017.

[11] K. Dutta, M.-Y. Lee, W. W.-P. Lai et al., "Removal of pharmaceuticals and organic matter from municipal wastewater using two-stage anaerobic fluidized membrane bioreactor," Bioresource Technology, vol. 165, pp. 42-49, 2014.

[12] M. Munir, K. Wong, and I. Xagoraraki, "Release of antibiotic resistant bacteria and genes in the effluent and biosolids of five wastewater utilities in Michigan," Water Research, vol. 45, no. 2, pp. 681-693, 2011.

[13] Z. Huang, S. L. Ong, and H. Y. Ng, "Feasibility of submerged anaerobic membrane bioreactor (SAMBR) for treatment of low-strength wastewater," Water Science \& Technology, vol. 58, no. 10, pp. 1925-1931, 2008.

[14] A. P. Trzcinski and D. C. Stuckey, "Anaerobic digestion of the organic fraction of municipal solid waste in a two-stage membrane process," Water Science \& Technology, vol. 60, no. 8, pp. 1965-1978, 2009.

[15] P. H. Wu, K. K. Ng, P. K. A. Hong, P. Y. Yang, and C. F. Lin, "Treatment of low-strength wastewater at mesophilic and psychrophilic conditions using immobilized anaerobic biomass," Chemical Engineering Journal, vol. 311, no. 1, pp. 46-54, 2017.

[16] J. Kim, K. Kim, H. Ye et al., "Anaerobic fluidized bed membrane bioreactor for wastewater treatment," Environmental Science \& Technology, vol. 45, no. 2, pp. 576-581, 2011.

[17] E. Jeong, H.-W. Kim, J.-Y. Nam, and H.-S. Shin, "Enhancement of bioenergy production and effluent quality by integrating optimized acidification with submerged anaerobic membrane bioreactor," Bioresource Technology, vol. 101, no. 1, pp. S7-S12, 2010.

[18] Z. Huang, S. L. Ong, and H. Y. Ng, "Submerged anaerobic membrane bioreactor for low-strength wastewater treatment: Effect of HRT and SRT on treatment performance and membrane fouling," Water Research, vol. 45, no. 2, pp. 705-713, 2011.

[19] APHA, WEF (1998) Standard methods for the examination of water and wastewater, American Public Health Association, Washington, DC, 1998.

[20] S. Malamis and A. Andreadakis, "Fractionation of proteins and carbohydrates of extracellular polymeric substances in a membrane bioreactor system," Bioresource Technology, vol. 100, no. 13, pp. 3350-3357, 2009.

[21] M. DuBois, K. A. Gilles, J. K. Hamilton, P. A. Rebers, and F. Smith, "Colorimetric method for determination of sugars and related substances," Analytical Chemistry, vol. 28, no. 3, pp. 350-356, 1956.

[22] J. Ma, Z. Wang, Y. Yang, X. Mei, and Z. Wu, "Correlating microbial community structure and composition with aeration intensity in submerged membrane bioreactors by 454 highthroughput pyrosequencing," Water Research, vol. 47, no. 2, pp. 859-869, 2013

[23] L.-W. Meng, X.-K. Li, K. Wang, K.-L. Ma, and J. Zhang, "Pretreating amoxicillin contained wastewater with an anaerobic 
expanded granular sludge bed (EGSB)," Desalination and Water Treatment, vol. 57, no. 34, pp. 16008-16014, 2016.

[24] R. K. Dereli, M. E. Ersahin, H. Ozgun et al., "Potentials of anaerobic membrane bioreactors to overcome treatment limitations induced by industrial wastewaters," Bioresource Technology, vol. 122, pp. 160-170, 2012.

[25] S. Aydin, Z. Cetecioglu, O. Arikan, B. Ince, E. G. Ozbayram, and O. Ince, "Inhibitory effects of antibiotic combinations on syntrophic bacteria, homoacetogens and methanogens," Chemosphere, vol. 120, pp. 515-520, 2015.

[26] M. M. Amin, J. L. Zilles, J. Greiner, S. Charbonneau, L. Raskin, and E. Morgenroth, "Influence of the antibiotic erythromycin on anaerobic treatment of a pharmaceutical wastewater," Environmental Science \& Technology, vol. 40, no. 12, pp. 39713977, 2006.

[27] H. J. Lin, K. Xie, B. Mahendran et al., "Sludge properties and their effects on membrane fouling in submerged anaerobic membrane bioreactors (SAnMBRs)," Water Research, vol. 43, no. 15, pp. 3827-3837, 2009.

[28] H. Lin, B.-Q. Liao, J. Chen et al., "New insights into membrane fouling in a submerged anaerobic membrane bioreactor based on characterization of cake sludge and bulk sludge," Bioresource Technology, vol. 102, no. 3, pp. 2373-2379, 2011.

[29] W. C. Kuo and G. F. Parkin, "Characterization of soluble microbial products from anaerobic treatment by molecular weight distribution and nickel-chelating properties," Water Research, vol. 30, no. 4, pp. 915-922, 1996.

[30] K. Yamamoto, M. Hiasa, T. Mahmood, and T. Matsuo, "Direct solid-liquid separation using hollow fiber membrane in an activated sludge aeration tank," Water Science and Technology, vol. 21, no. 4-5, pp. 43-54, 1988.

[31] F. Meng, H. Zhang, F. Yang, Y. Li, J. Xiao, and X. Zhang, "Effect of filamentous bacteria on membrane fouling in submerged membrane bioreactor," Journal of Membrane Science, vol. 272, no. 1-2, pp. 161-168, 2006.

[32] D.-W. Gao, T. Zhang, C.-Y. Y. Tang et al., "Membrane fouling in an anaerobic membrane bioreactor: differences in relative abundance of bacterial species in the membrane foulant layer and in suspension," Journal of Membrane Science, vol. 364, no. 1-2, pp. 331-338, 2010.

[33] Y. Zhang, J. Xie, M. Liu et al., "Microbial community functional structure in response to antibiotics in pharmaceutical wastewater treatment systems," Water Research, vol. 47, no. 16, pp. 6298-6308, 2013.

[34] A. El Kasmi, S. Rajasekharan, and S. W. Ragsdale, "Anaerobic pathway for conversion of the methyl group of aromatic methyl ethers to acetic acid by Clostridium thermoaceticum," Biochemistry, vol. 33, no. 37, pp. 11217-11224, 2002.

[35] J. Winter, M. R. Popoff, P. Grimont, and V. D. Bokkenheuser, "Clostridium orbiscindens sp. nov., a human intestinal bacterium capable of cleaving the flavonoid C-ring," International Journal of Systematic Bacteriology, vol. 41, no. 3, pp. 355$357,1991$.

[36] Y. Deng, Y. Zhang, Y. Gao et al., "Microbial community compositional analysis for series reactors treating high level antibiotic wastewater," Environmental Science \& Technology, vol. 46, no. 2, pp. 795-801, 2011.

[37] H. Wang, Y. Qu, D. Li et al., "Cascade degradation of organic matters in brewery wastewater using a continuous stirred microbial electrochemical reactor and analysis of microbial communities," Scientific Reports, vol. 6, no. 1, p. 27023, 2016.
[38] H. Ozgun, Y. Tao, M. E. Ersahin et al., "Impact of temperature on feed-flow characteristics and filtration performance of an upflow anaerobic sludge blanket coupled ultrafiltration membrane treating municipal wastewater," Water Research, vol. 83, no. 15, pp. 71-83, 2015.

[39] H. Wang, Y. Tao, D. Gao et al., "Microbial population dynamics in response to increasing loadings of pre-hydrolyzed pig manure in an expanded granular sludge bed," Water Research, vol. 87, no. 15, pp. 29-37, 2015.

[40] X. Zheng, Y. Su, X. Li, N. Xiao, D. Wang, and Y. Chen, "Pyrosequencing reveals the key microorganisms involved in sludge alkaline fermentation for efficient short-chain fatty acids production," Environmental Science \& Technology, vol. 47, no. 9, pp. 4262-4268, 2013.

[41] T. Yamada, H. Imachi, A. Ohashi et al., "Bellilinea caldifistulae gen. nov., sp. nov. and Longilinea arvoryzae gen. nov., sp. nov., strictly anaerobic, filamentous bacteria of the phylum Chloroflexi isolated from methanogenic propionate-degrading consortia," International Journal of Systematic and Evolutionary Microbiology, vol. 57, no. 10, pp. 2299-2306, 2007.

[42] T. Yamada, Y. Sekiguchi, S. Hanada et al., "Anaerolinea thermolimosa sp. nov., Levilinea saccharolytica gen. nov., sp. nov. and Leptolinea tardivitalis gen. nov., sp. nov., novel filamentous anaerobes, and description of the new classes Anaerolineae classis nov. and Caldilineae classis nov. in the bacterial phylum Chloroflexi," International Journal of Systematic and Evolutionary Microbiology, vol. 56, no. 6, pp. 1331-1340, 2006.

[43] D. S. M. Ghasimi, Y. Tao, M. de Kreuk, B. Abbas, M. H. Zandvoort, and J. B. van Lier, "Digester performance and microbial community changes in thermophilic and mesophilic sequencing batch reactors fed with the fine sieved fraction of municipal sewage," Water Research, vol. 87, no. 15 , pp. 483-493, 2015.

[44] D. S. M. Ghasimi, Y. Tao, M. de Kreuk, M. H. Zandvoort, and J. B. van Lier, "Microbial population dynamics during longterm sludge adaptation of thermophilic and mesophilic sequencing batch digesters treating sewage fine sieved fraction at varying organic loading rates," Biotechnology for Biofuels, vol. 8, no. 1, p. 171, 2015.

[45] W. Gujer and A. J. Zehnder, "Conversion processes in anaerobic digestion," Water Science and Technology, vol. 15, pp. 127167, 1983.

[46] V. Razaviarani and I. D. Buchanan, "Reactor performance and microbial community dynamics during anaerobic co-digestion of municipal wastewater sludge with restaurant grease waste at steady state and overloading stages," Bioresource Technology, vol. 172, pp. 232-240, 2014. 


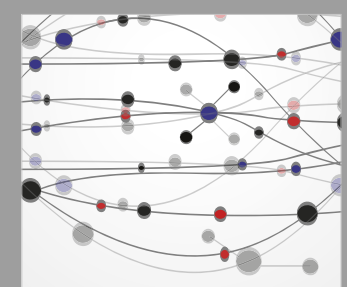

The Scientific World Journal
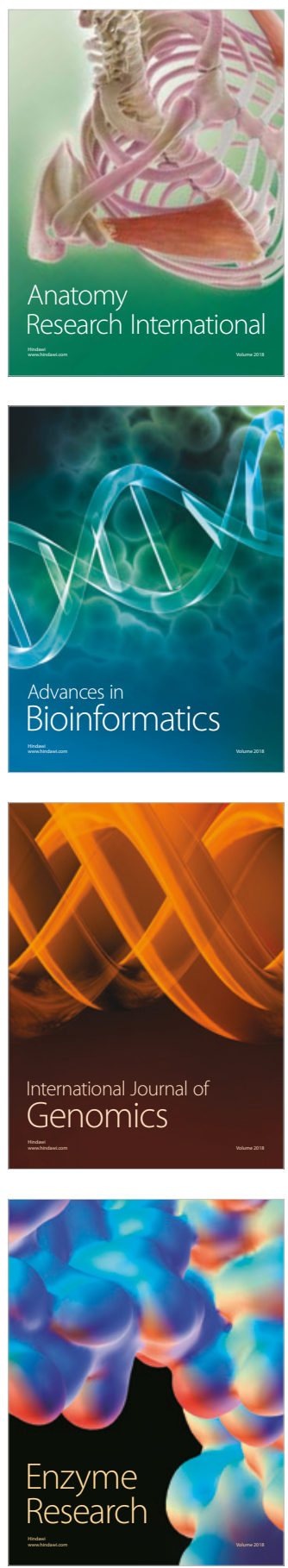
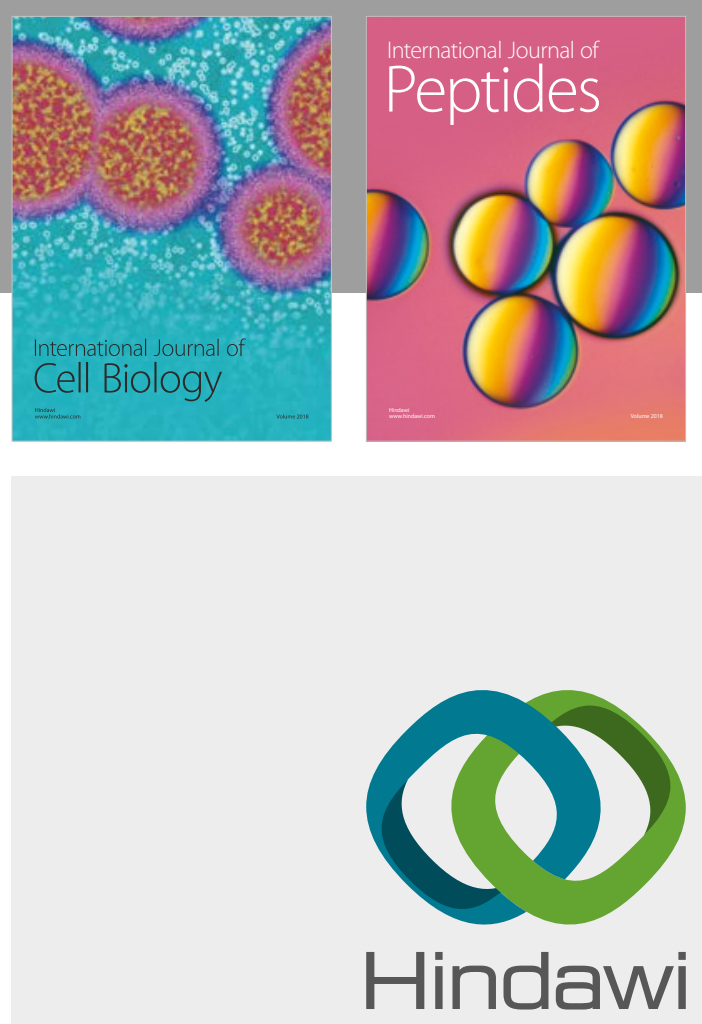

Submit your manuscripts at

www.hindawi.com
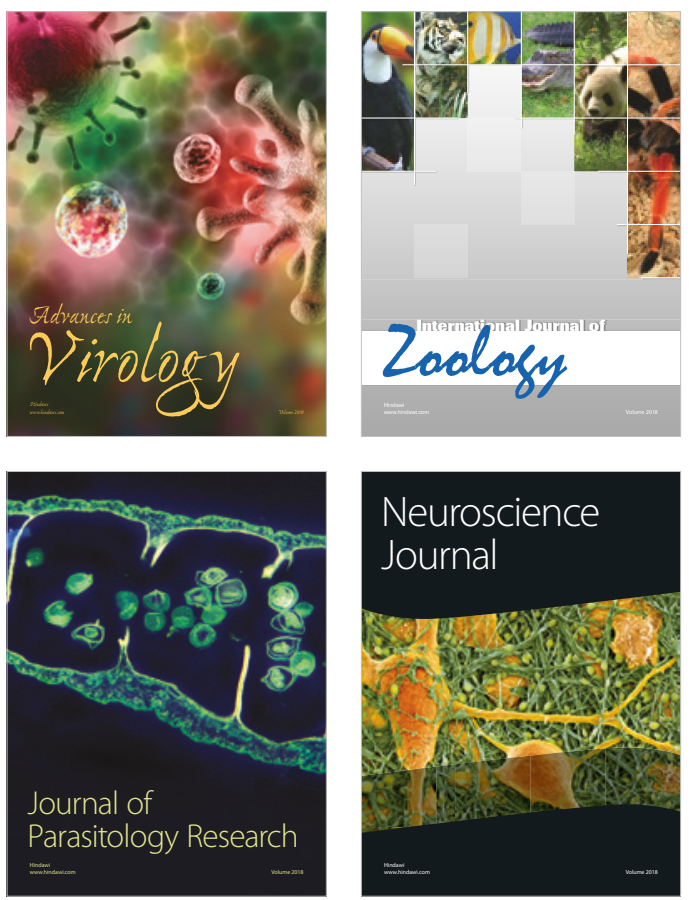
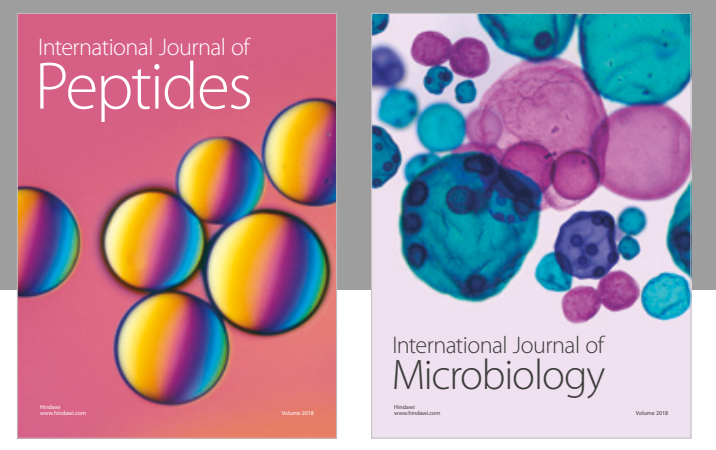

nternational Journal of Microbiology
Journal of
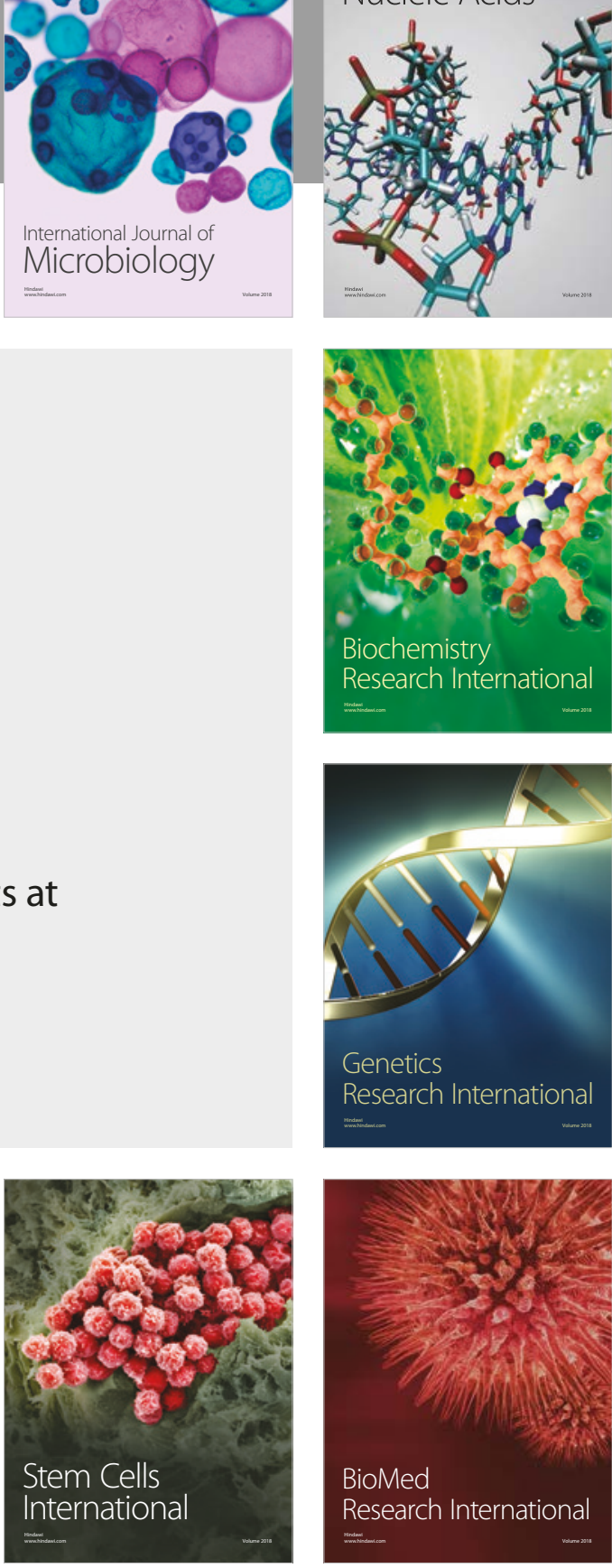
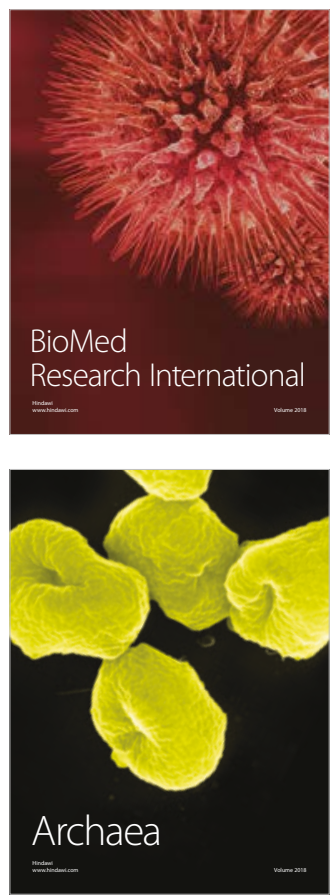